\title{
Fiscal policy and social protection in Chile
}

\author{
Alberto Arenas de Mesa \\ Assistant Director, \\ Budgetary Affairs Bureau, \\ Chilean Ministry of Finance \\ aarenas@dipres.cl \\ Julio Guzmán Cox \\ Economist, \\ Research Department, \\ Budgetary \\ Affairs Bureau, \\ Chilean Ministry \\ of Finance \\ jguzman@dipres.cl \\ Stable development and financing of the social protection \\ system, one of the priorities of fiscal policy in Chile over \\ recent years, has helped to reduce poverty and indigence, \\ particularly since the 1990 s. The fiscal accounts have been \\ managed prudently, and budgetary balance and efficient \\ administration have been given priority over short-term \\ objectives. Even so, poverty is still a fact of life and the \\ poor are still vulnerable to drastic falls in income. This means \\ that an effort is still required to modernize fiscal policy and \\ develop new institutional arrangements for the social \\ protection system. This paper analyses the challenges \\ involved and the relationship among the different roles \\ played by fiscal policy in Chile over recent years.
}




\section{I}

\section{Introduction}

The main functions performed by fiscal policy in Chile over recent years include the following: i) it has contributed to macroeconomic stability and thereby fostered economic growth; ii) it has generated stable, balanced financing for the social protection system, whose development has been made possible in part by these favourable conditions; and iii) it has influenced the institutional framework for social policy and the basic system of social protection. This paper explores and examines these functions, looks at the relationships among them and considers how closely they are linked together in the fiscal and social experience of Chile in recent years.

The globalization of financial markets has made fiscal stability ever more important. Increasing economic globalization and market integration have generated enormous growth and development opportunities for the economies of Latin America. At the same time, however, and as the incomes, consumption opportunities and well-being of people in emerging economies have increased, they have become more vulnerable to fluctuations in the world economy. The extra risk associated with countries' increased exposure to external factors has been accompanied by the development of insurance markets and institutional and non-institutional protection mechanisms.

In this constantly evolving economic context, social protection policies are becoming more and more important, not just as a means to equity but also as part of an economic development strategy to cover the basic risks facing lower-income sectors and thereby enable them to take more proactive decisions in their quest to overcome poverty. The social protection system seeks to reduce the vulnerability or risks faced by the poorest when shocks occur, in Chile or elsewhere.

In recent years, one of the priorities of fiscal policy has been to develop the social protection system and provide it with stable financing. Although reducing poverty and indigence and combating inequities have

$\square$ The contents of this document are the sole responsibility of the authors and do not necessarily reflect the views of the organizations to which they belong. been the main thrusts of social policy, poverty is still a fact of life and the poor remain vulnerable to drastic falls in income.

The recent international economic crises severely affected the economies of Latin America and highlighted the situation of fiscal imbalance in which many of them were placed, requiring painful economic adjustments that intensified rather than mitigated the impact of the crises. In the case of the Chilean economy, success in reconciling strong growth in social spending with a sound, balanced fiscal policy has made it possible to implement a large range of temporary measures in crisis periods that have cushioned the basic consumption patterns of the lowerincome population.

Chile is thus seen as an example of prudent, orderly fiscal management in which efficient administration and budgetary balance have been given priority over shortterm objectives and sustained fiscal support for social development has been successfully reconciled with a considerable reduction in public debt.

In this context, it is more and more important to pursue fiscal responsibility so that the public finances can be managed sustainably. To reduce macroeconomic volatility, however, it is also necessary to allow fiscal policy to play a countercyclical role. In Chile, the fiscal rule that consists in maintaining a structural surplus of $1 \%$ of gross domestic product (GDP) is applied for precisely this purpose.

The argument is that applying the $1 \%$ of GDP rule allows public spending decisions to be based on the more permanent availability of financing, so that temporary revenue surges generated by the economic cycle are not relied upon as a basis for spending, and so that drops in revenue known to be temporary do not result in unnecessary spending cuts. The benefits sought are medium-term macroeconomic balance and minimization of cycle-related costs (Ministry of Finance, 2002b). The idea is that structural balance should improve both transparency and flexibility in the management of the public finances at any given point in the cycle and should help make fiscal policy a key instrument in promoting macroeconomic stability and growth in the medium and long term.

The subject is a particularly important one where social protection is concerned, since if future fiscal 
commitments are not properly anticipated there is the risk that resources intended for social purposes may at some point have to be diverted to cover liabilities as they arise over time. This is why it is important to consider the management of contingent liabilities as one of the medium-term aspects of social protection policies.

The task of fiscal policy is not over when it has contributed to macroeconomic stability and stable financing of the social protection system. On the contrary, it has an active role to play in the development and implementation of the system of public and semipublic institutions in which social policies and programmes operate. In other words, fiscal policy is not neutral vis-à-vis the social protection structures that arise as a result of its action.

This document contains four sections besides this introduction. Section II provides a summary of macroeconomic fiscal policy and the policy of structural balance. Section III describes the social protection system and its effects in reducing poverty and redistributing income. Section IV shows the relationships between fiscal policy and the institutional framework for social programmes, and details the most important contingent liabilities. Lastly, section $\mathrm{V}$ offers some final remarks and conclusions.

\section{II}

\section{Macroeconomic fiscal policy}

\section{Fiscal responsibility and social protection}

Over the economic cycles of the last two decades, fiscal responsibility has become increasingly important to economic management, and this is particularly true where social policies in Latin America are concerned. The large adjustments of the 1980s and the current situation in some countries have shown very starkly that irresponsible management of the public finances can have very adverse economic and social consequences.

Fiscal stability has increasingly been a key factor in the sustained development of social policy institutions, and it is particularly crucial at a time when the globalization of financial markets has become a reality. The procyclical nature of short-term international capital and the vital role played by changes in the terms of trade have led countries to design mechanisms for self-insurance (such as stabilization funds) and risk diversification (such as investments abroad) to mitigate the effects of economic crises on the public finances (De Ferranti, Perry and others, 2000). This makes it less likely that the budgets of the different social programmes will have to be cut.

In addition to this, the way the public finances and their link with social protection are regarded in economic terms has been tending to shift in recent years. There has been a gradual movement away from shortterm analysis centring on aggregate demand and the liquidity available for financing and towards a medium- term outlook centring on the scope for meeting the needs of the population at times of crisis, on financial sustainability, on fiscal risks, on intertemporal budgetary constraints and on public-sector management efficiency.

In this context, Chile stands out as an example of prudent, orderly fiscal management suitably combined with steady development of social policies. ${ }^{1}$ Efficient administration and budgetary balance have been given priority over short-term objectives, and this has meant a greater capacity to respond to the social demands that arise at times of crisis. During the 1990s, in fact, fiscal support for social development was sustained even during the economic slowdown of 1998-2002, while between 1989 and 2002 gross central government debt was reduced from $43.8 \%$ to $15.9 \%$ of GDP. ${ }^{2}$

This reduction in the public debt burden has important consequences for the country's ability to maintain steady, stable growth in fiscal social spending

\footnotetext{
${ }^{1}$ See Marcel and Tokman (2002) for an analysis of the main fiscal reforms implemented in Chile over recent years.

${ }^{2}$ In relative terms, this debt now compares favourably with the figures for other countries. In the case of the most advanced Organisation for Economic Co-operation and Development (OECD) countries, for example, gross central government debt averaged $73 \%$ of GDP in 2001, ranging from a low of $18 \%$ for the Republic of Korea to a high of $132 \%$ for Japan. To compare with other countries, gross general government debt ranges from $24 \%$ of GDP in the Czech Republic to $70 \%$ in Brazil (Ministry of Finance, 2002a).
} 
even at times of crisis. Firstly, the reduction in debt has meant that substantially fewer resources are required to service it, and this has direct consequences in that it provides greater scope for fiscal policy to redirect resources to social areas. Secondly, maintaining a low level of public borrowing acts as a national protection strategy, as fiscal adjustments are less likely to be needed when interest rates rise sharply and when international capital proves volatile, as it does in times of crisis. Furthermore, lower public debt means that the public sector can be more selective in its use of external credit. This was the case with the sovereign bond operations of the 2000-2002 period, which were a step forward in consolidating the country's financial position.

The fiscal policy debate in Latin America has centred on long-term financial sustainability, often ignoring the effects of procyclical bias in fiscal policy and the business cycle. Perry (2002) maintains that this is a serious mistake, because in Latin America procyclical policies have a huge cost in terms of growth and welfare, especially for the poorest. Procyclical fiscal policies and rules, he adds, tend to generate deficits so that ultimately they are neither sustainable nor credible.

The instability of fiscal policies is probably one of the underlying causes of macroeconomic volatility in Latin America (De Ferranti, Perry and others, 2000). For the public finances to be sustainable over time, therefore, it is crucial that there be fiscal responsibility. Yet fiscal policy also has to be allowed to play a countercyclical role if macroeconomic volatility is to be reduced, so that social policies do not have to be sacrificed at times of crisis. This is one of the objectives of the fiscal policy rule applied in Chile, which is analysed below.

\section{Structural balance and the fiscal policy rule: rigidity or flexibility?}

Macroeconomic fiscal policy has two overarching objectives: to play a short-term stabilizing role and to pursue long-term sustainability. In some economies, pressures from society or interest groups often result in the second objective being subordinated to the first, which can trigger unsustainable fiscal deficits. Welldesigned fiscal policy rules can reconcile these two overarching objectives.

Thus, in 2000 Chile brought in an explicit rule for the formulation, management and evaluation of fiscal policy that consists in maintaining a structural central government surplus of $1 \%$ of GDP. Its objectives, the structure of the fiscal policy indicator and its advantages and limitations are described below.

\section{a) Objectives of the structural balance indicator and} the fiscal policy rule

The specific objectives pursued by the fiscal policy rules applied in various OECD countries include the following: i) ensuring macroeconomic stability; ii) enhancing the credibility of fiscal policy and helping to stabilize the public debt; iii) ensuring the long-term sustainability of fiscal policy; iv) minimizing the negative externalities of international treaties, such as the Maastricht Treaty; and v) reducing the procyclical bias of fiscal policy.

The objective of the fiscal policy rule in Chile, it has been argued, is to ensure that public spending decisions take account of the availability of more permanent financing, so that temporary revenue surges arising from the business cycle are not relied upon as a basis for spending, and so that revenue losses known to be temporary do not result in unnecessary expenditure cuts. The aim of this is to ensure medium-term macroeconomic balance and to minimize cycle-related costs (Ministry of Finance, 2002b). The idea is that structural balance should increase both transparency and flexibility in the management of the public finances at any given point in the cycle and should help make fiscal policy a key factor in macroeconomic stability and growth in the medium and long term (Marcel, Tokman and others, 2001).

\section{b) Estimating the structural balance}

Of the various fiscal policy indicators available in Chile, the one chosen was the structural balance indicator, partly because the International Monetary Fund (IMF) and OECD recognize, validate and apply its methodology. Although it does not in itself entail a fiscal policy rule, this indicator provides a basis for establishing the $1 \%$ of GDP structural surplus rule.

To calculate the public-sector structural balance in Chile, the IMF criteria for estimating structural balances in developed countries were adopted. The standard methodology followed by that organization was adjusted in two ways to reflect the special characteristics of the Chilean public sector. Firstly, expenditure was not adjusted for the business cycle because there are no spending programmes that respond automatically to that cycle. Secondly, a specific adjustment was added for copper revenue, as this is a major source of fiscal revenue deriving from the exploitation of a raw material whose price exhibits reversion to the mean. 
The public-sector structural balance thus reflects what the amount of fiscal revenue and expenditure would be if output were at its potential level and the copper price were at its medium-term average. It therefore excludes the cyclical and aleatory effects of two factors that are of vital importance in Chile: economic activity and the copper price.

The structural balance is estimated in three stages. First, the adjusted balance is estimated. Accounting adjustments are made to the actual balance to determine the revenue and expenditure items to be included in the adjusted balance so that it reflects net asset variation in the public sector. Second, the cyclical components of the budget are estimated, namely the effects of cyclical changes in economic activity and the copper price on fiscal aggregates. Two bodies were set up to estimate the copper price and the level of activity in the long term, each of them staffed by independent experts: the Comité Consultivo del Precio de Referencia del Cobre (Copper Reference Price Consultative Committee) and the Comité Consultivo del PIB Potencial (Potential GDP Consultative Committee). The third stage consists in estimating the structural balance from the adjusted balance and from the cyclical components calculation. ${ }^{3}$

c) Advantages and limitations of the fiscal policy rule

Since 2001, the public finances of the central government have been managed in accordance with the $1 \%$ of GDP structural surplus rule. Although this rule has only been operating for a short time, it is possible to identify a number of benefits deriving from its application in the last three financial years.

Firstly, the policy rule has helped guide the expectations of economic agents concerning the direction of fiscal policy, allowing the benefits of future prudence to be reaped immediately. Its application has provided a signal of fiscal austerity and responsibility at a particularly difficult time for the international economy. Thus, one of the clear consequences of this signal at the present time is that Chile's country risk, as measured by the spread of sovereign debt, has remained extraordinarily low. This has protected the Chilean economy and set it apart from the other countries of Latin America (figure 1).

\footnotetext{
${ }^{3}$ See Marcel, Tokman and others (2001) for a detailed explanation of the methodological aspects and procedure involved in estimating the structural balance.
}

FIGURE 1

Latin America (four countries): Country risk as measured by the spread of sovereign debt over United States treasuries

(Basis points)

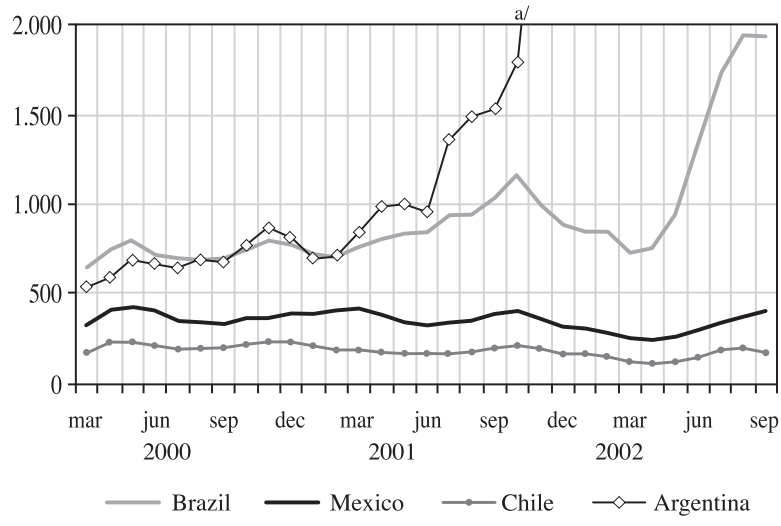

Source: JP Morgan Chase.

a/ Values in excess of 2000.

Similarly, the rapid structural improvement in the public finances in 2000 created the confidence and scope for the public sector to play a countercyclical role in 2001 and 2002. Internationally, this countercyclical character of the public finances is one of the most striking features of Chilean macroeconomic policy.

The policy rule has therefore made it possible to reconcile two complementary objectives that are highly desirable for an economy which depends as heavily on external conditions as the Chilean economy does: strengthening fiscal discipline and playing a countercyclical role. Fiscal discipline has been strengthened in the medium term by concentrating on intertemporal financial sustainability and not on the short-term liquidity available for financing. The effect of this has been to reassure economic agents and investors that accounting deficits are essentially transitory and that financing needs are being kept down to a level compatible with the capacity to generate fiscal revenue over the medium term. The countercyclical role, from a modern point of view, has taken account of the costs entailed by a procyclical fiscal policy in terms of growth and welfare (particularly that of the poorest), one of the characteristic weaknesses of developing economies. In fact, moderating the growth of fiscal expenditure over time makes it less likely that fiscal adjustments will be needed and allows social policy institutions to develop more steadily.

In consequence, the structural surplus rule has not brought any additional rigidity to fiscal policy. Rather, 
it has set definite pre-announced limits to accounting deficits, and these have provided the flexibility needed to support economic growth, investment and the development of social policies at times of particular difficulty.

Where social policies are concerned, unqualified commitment to the $1 \%$ of GDP structural deficit target has helped reconcile fiscal austerity with the sustained development of social protection policy institutions. The stability that the application of this rule has brought to the development of public policies is at least as important as the countercyclical capacity of the public finances and the credibility of the medium-term signal that this generates. Application of the structural surplus rule, combined with a major effort to reallocate resources, has made it possible to carry on increasing public-sector social and investment spending and to implement new programmes to deal with the consequences of the economic slowdown.

This is reflected, among other factors, in the recent growth of social spending and public-sector investment, which increased respectively by an estimated $5.8 \%$ and $7.9 \%$ in real terms annually between 2001 and 2003. As table 1 shows, the above-average increases in this priority spending over the last two years were achieved through an effort to contain inertial growth in other expenditure. The table also shows that while social and investment spending saw this strong growth in 20012003, expenditure on defence and operating costs (staff and the procurement of goods and services) rose more slowly than the average for the 1990s.

As for the limitations of the policy rule, these include the lack of a legal framework to underpin its application and ensure that its continuity does not depend only on the political will of the present

TABLE 1

Chile: Central government spending

(Annual percentage change in real terms)

\begin{tabular}{lcc}
\hline Expenditure type & $\begin{array}{c}\text { Actual } \\
\text { spending } \\
1990-2000\end{array}$ & $\begin{array}{c}\text { Budgeted } \\
\text { spending } \\
2001-2003\end{array}$ \\
\hline $\begin{array}{l}\text { Total expenditure } \\
\text { Economic classification } \\
\quad \text { Operating costs }\end{array}$ & 6.6 & 4.6 \\
$\quad \begin{array}{l}\text { Real investment and } \\
\text { capital transfers }\end{array}$ & 6.7 & 4.1 \\
$\begin{array}{l}\text { Functional classification } \\
\text { Defence }\end{array}$ & 9.6 & 7.9 \\
Social spending & 3.6 & 1.9 \\
\hline
\end{tabular}

Source: Dirección de Presupuestos, Ministry of Finance.
Government. Although this has not undermined its credibility in practice, it is worth considering what mechanisms can be created to institutionalize it. The international evidence regarding legal backing of this type is very varied, however. Even if a legal instrument has been put in place to establish the fiscal rule, it is essential for effectiveness that it should be plausible, which means that its design needs to allow for continuing application by successive governments. In the long run, this will depend not necessarily on the force of the legal instrument establishing the rule, but on whether it has been complied with in the past and what costs would be entailed by breaking it in future. The more institutionalized it is, the higher these costs will be.

\section{The role of countercyclical fiscal policy in social protection}

The policy rule has allowed social fiscal spending to play a countercyclical role in a context of high external volatility. It is necessary to ask, however, what consequences the existence or otherwise of countercyclical fiscal policies has for social protection.

The question is relevant, particularly for the countries of Latin America, because there is a strong perception of economic insecurity even in the countries with the best development prospects (De Ferranti, Perry and others, 2000). Along with this greater concern about economic insecurity, there are signs of unmet demand for social protection. It has been argued that this is partly because market development and structural reforms have not been matched by the parallel development of an adequate system of social protection.

This is particularly worrying if we consider that the poor are those most affected at times of crisis because they lack the means to protect themselves, such as financial assets, and because they are directly affected by falling incomes from work. In addition, increased employment for poor families during upturns is generated in the informal sector (Tokman, 2001).

In this context, fiscal policy has an important role to play in targeting the most vulnerable and worst affected groups and in seeking a greater countercyclical role at times of crisis.

The reality in Latin America, however, is far different. In most of the region's economies, fiscal policy has not succeeded in discharging its stabilizing function. Governments have generally adopted an expansionary stance during upturns, then applied contractionary policies in downturns. As a result, social 
spending on the poor is cut in recessions. The procyclical nature of this spending results in a lack of social protection during times of hardship, which are exactly when it is most needed. ${ }^{4}$

In past crises, Chile was no exception. In 1975 and 1982, for example, economic activity declined by more than $13 \%$ in real terms in one year, while unemployment rose to $30 \%$. In 1999 the Chilean economy was more robust, but the Asian crisis still resulted in a $1.1 \%$ fall in activity and unemployment approached $10 \%$ that year. In those periods, meanwhile, total public spending behaved procyclically (with the exception of 1999). In 1975 it actually fell by $23 \%$, while in the 1982-1983 period public-sector investment fell by an average of $13 \%$ a year.

As already mentioned, one of the benefits of today's fiscal policy management using the structural balance rule is the scope it offers for reconciling increased spending with macroeconomic balance in difficult periods. Even in present circumstances, in fact, the policy combination adopted meant that output grew by $2.1 \%$ in real terms in 2002 .

The first step towards fiscal stability is to put the public finances on a sustainable path. Chile has led the way here, as in recent decades reserves have been saved and put aside against difficult periods.

The second step is give fiscal policy a countercyclical role that reduces aggregate volatility. The $1 \%$ of GDP structural surplus rule plays an important role in social protection. In this respect, the rule falls into the category of "self-insurance" mechanisms (Fiess, 2002). Accumulating resources during upturns means that more can be done in difficult times. At the same time the rule has the characteristics of a "selfprotection" mechanism, since by following it Chile has reduced the likelihood of contagion from crises

\footnotetext{
${ }^{4}$ See De Ferranti, Perry and others (2000, chapter 7), Wodon, Hicks and others (1999) and Snyder and Yackovlev (2000) for an analysis of the evidence on this point.
}

affecting nearby countries and has differentiated itself from the rest of Latin America.

The current fiscal policy rule, based on maintaining expenditure growth at a level similar to that of structural revenue growth, dampens the cycle and mitigates its effects. During upturns, fiscal revenue increases and is saved, which relieves the pressure on aggregate demand. This contrasts with cases where these resources are spent by the treasury or simply returned to individuals. During times of recession, spending temporarily rises by more than output and tax revenues, the difference being made up from alternative sources of financing.

Notwithstanding the above, one possible way of enhancing the countercyclical nature of fiscal policy that has come up in a theoretical context is to improve the design of targeted programmes in relation to the economic cycle. From the point of view of social protection, it may be advisable to increase the countercyclical component of some targeted expenditure items or transfers that especially reach the poorest population. One way of preventing the dynamic of total expenditure from shifting over the course of the cycle might be to make other fiscal spending more procyclical or flexible, which would mean lessening the inertia of a large proportion of total expenditure. In many cases this tends not to be feasible, for example where staff or pension expenses are concerned, which makes this goal even harder to achieve..$^{5}$ If it were done, however, it would be possible to achieve total spending growth in line with structural revenues while enhancing the countercyclical character of targeted social spending. Although this situation really shows a lack of flexibility in fiscal expenditure, it is important to bear it in mind because it could limit the effectiveness of fiscal policy as a social protection mechanism for the poorest.

\footnotetext{
${ }^{5}$ In 2001, pension and staff expenditure accounted for some $48 \%$ of total spending by central government in Chile.
} 


\section{III \\ The social protection system and fiscal policy}

The earliest forms of social protection applied in Chile derived from the social theories formed in the late nineteenth century. The first social assistance and protection networks were created between this period and the early decades of the following century. The initiatives adopted included bills to mandate the construction of workers' housing and the approval of tax incentives for building, compulsory basic education and the health code (Arellano, 1985). These were some of the earliest pillars of a social network that by 2002 accounted for over $16 \%$ of GDP.

In the area of social protection, in particular the traditional and contributory systems, the so-called social laws enacted during the first term of Arturo Alessandri (1924) were the earliest social security measures applied in Chile and were based on the German experience or model designed by Bismarck the previous century. The system was one of social insurance differentiated by occupation. A second stage, lasting from the 1960s until 1980 , took the universalization approach to social security formulated in the Beveridge Plan. The third stage, which is the current one, began in 1980. Its main thrust is towards privatization of the management of protection mechanisms (Arenas de Mesa, 2000).

There now coexist, in an odd mixture, a social insurance structure along the lines of the early German model that is being wound down for the most part, consisting in the pension systems tailored to different occupations that are run by the Institute of Social Security Standardization (INP) and are still fully operational for the military; a set of universal social insurance schemes, many of them with elements of social assistance, answering to Beveridge's conception of social insurance; and, lastly, insurance schemes administered by the private sector, either on a pooled basis as in the case of the pension fund managers (AFPs) in respect of pensions, or on an alternative or optional basis as in the case of the private health insurance institutions (Isapres) in the health field.

The fact that over three million people are living in poverty in Chile (Casen 2000 survey) means there is a great need to strengthen the social protection system in future. The tailing off of progress with poverty reduction between 1998 and 2000 because of the adverse international economic situation shows how important this task is. Between 1990 and 1998, the proportion of people living in poverty fell from $38.6 \%$ to $21.7 \%$ of the total population, whereas in 2000 the incidence of poverty fell only to $20.6 \%$. The indigence rate fell from $12.9 \%$ to $5.6 \%$ between 1990 and 1998, but in 2000 it rose slightly to $5.7 \%$.

To deal with the new challenges, the social protection system will have to modernize and change its institutional structure. The efforts of protection networks will need to be coordinated and administered more efficiently, and institutions will need to be more flexible and decentralized. Information-gathering followed by the creation of a social protection information system, along with a new institutional structure for public-sector social protection policies, will need to be the basic pillars upon which a new social order can be built and consolidated in Chile (Arenas de Mesa and Benavides, 2003).

\section{Public spending and poverty}

One of the main objectives of fiscal policy has been the development and stable financing of social policies and the social protection system. Meanwhile, reducing poverty and indigence and combating inequity have been the main objectives of social policy. Poverty is still a fact of life, however, and the poor are still unable to meet their basic needs, while remaining vulnerable to drastic falls in income.

Between 1990 and 2001, the size of the State, measured by public spending as a share of GDP, rose from $20.2 \%$ to $23.5 \%$ (figure 2). In Chile, major social reforms were introduced during the 1990s and many new programmes were begun. Between 1990 and 2000, social spending rose by an average of $7.9 \%$ a year in real terms, while in the same period total central government spending grew by an average of $6.6 \%$ a year in real terms. When the sectoral composition of social spending is analysed, what stands out is the growth in education spending, which increased by an average of $10.6 \%$ a year in real terms. It was followed 
FIGURE 2

Chile: Social spending and total public spending as a percentage of GDP, 1990-2001

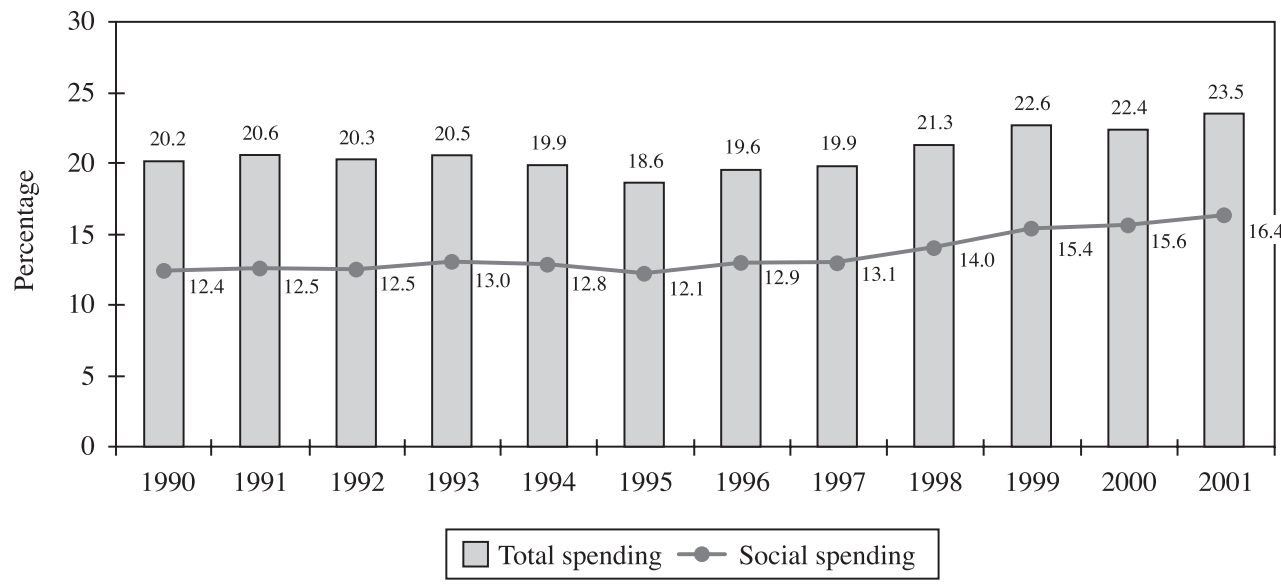

Source: Dirección de Presupuestos (2000 and 2001b).

FIGURE 3

Chile: Social spending as a percentage of total public spending, $1990-2001^{\text {a/ }}$

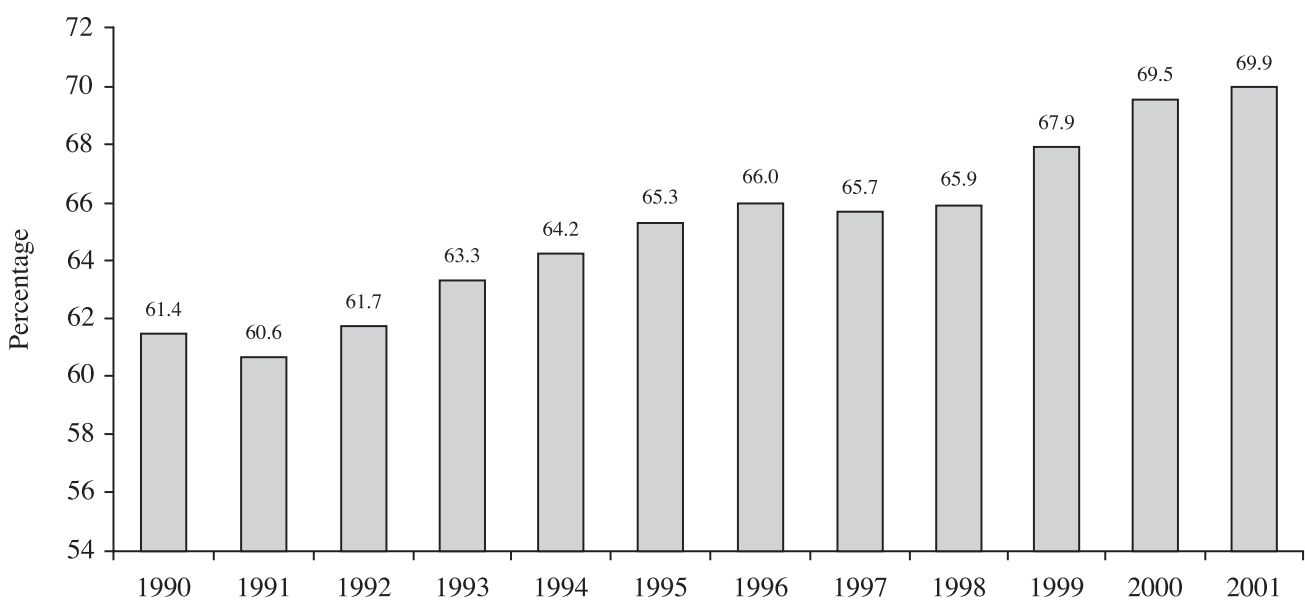

Source: Dirección de Presupuestos (2001b and 2002).

a/ Central government spending.

by health spending, which grew by an average of $9.4 \%$ a year.

With this rate of growth social spending has substantially increased its share of the total, from $61.4 \%$ in 1990 to $69.9 \%$ in 2001 (figure 3). If social spending is broken down by sector, it transpires that the share going to education rose from $20 \%$ to $26 \%$, while that going to health rose from $15 \%$ to $18 \%$ over the period. At the same time, pension spending fell from $49 \%$ to
$40 \%$ of social spending and housing expenditure from $7 \%$ to $6 \%$. The growth in social spending took it from $12.4 \%$ of GDP in 1990 to $16.4 \%$ in 2001 (figure 2).

From the social point of view, positive results have included a reduction in poverty from $38.6 \%$ of the population in 1990 to $20.6 \%$ in 2000 , and of indigence from $12.9 \%$ in 1990 to $5.7 \%$ in 2000 (figure 4). As a proportion of households, poverty fell from $33.3 \%$ to $16.6 \%$ and indigence from $10.6 \%$ to $4.6 \%$ in the same 
FIGURE 4

Chile: Change in the incidence of poverty and indigence

(Percentage of total population)

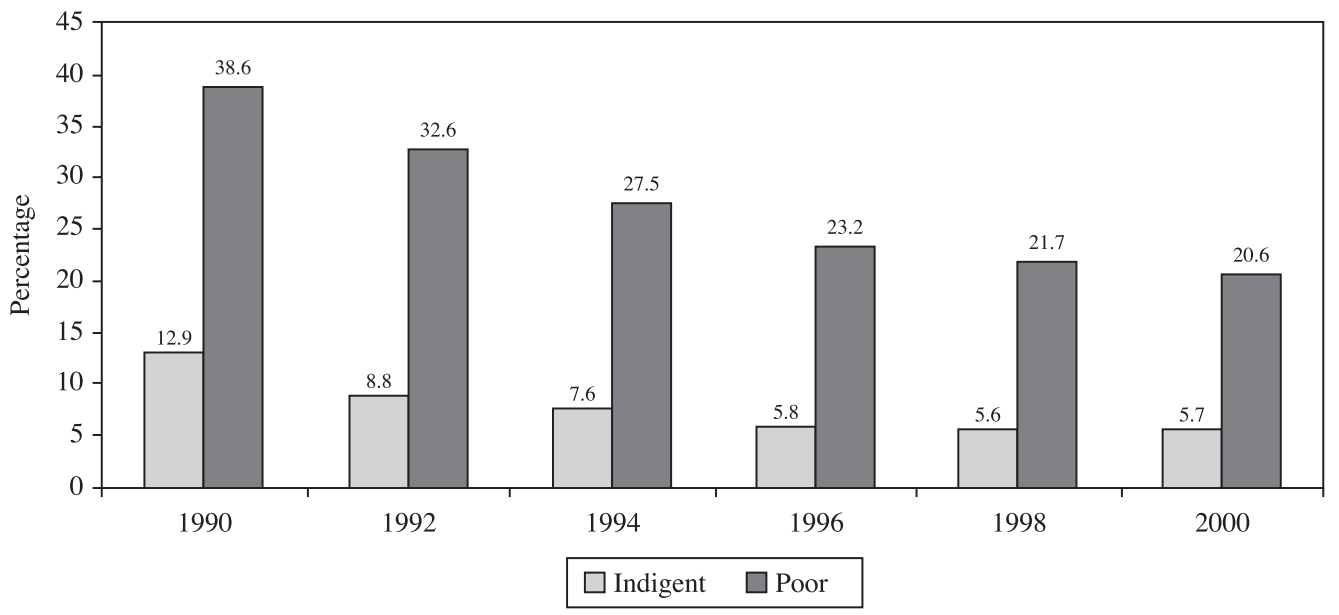

Source: Mideplan (2001).

period. The average gap between the incomes of the population as a whole and those of the poor and indigent also fell significantly, from 14.8 to 7.1 times in the case of the poor and from 4.3 to 2.1 times in the case of indigence.

\section{Coverage of the social protection system by function}

The system of social protection can be classified by its functions as they relate to old age, survivors, disability, occupational accidents and diseases, the family (children and sickness), health care, public health, employment, unemployment, poverty and social exclusion. Table 2 analyses the coverage of the functions served by the system for selected population groups. Employees are covered by all the programmes of the social protection network, but this is not the case with own-account workers, whose coverage will depend on membership of and actual contributions to the system, among other factors. Both contributory and non-contributory systems have varying requirements, particularly as regards means testing in the case of noncontributory systems. The system of social protection for informal sectors and for family, temporary and selfemployed workers is less comprehensive than that for employed workers owing, among other factors, to the characteristics of the population and the labour market at the time the programmes concerned were created. One of the challenges for the future is to consider how the system can be modified or redesigned to deal with the situation of these population groups.

\section{The social protection system and its distributive effect}

In 2002 , about $1,884,500$ fewer people were living in poverty than in 1990 . Nonetheless, inequality has remained virtually unchanged.

To take the distribution of autonomous income, between 1990 and 2000 the share of total income received by the first decile (lowest incomes) fell from $1.4 \%$ to $1.1 \%$, while the tenth decile (highest incomes) increased its share from $42.2 \%$ to $42.3 \%$ in the same period. The distribution of monetary income, which includes autonomous income and cash benefits, is still quite regressive. In the 1990-2000 period, the income share of the first decile fell from $1.6 \%$ to $1.5 \%$ of the total, while that of the tenth decile fell from $41.8 \%$ to $41 \%$.

In 1990, the Gini coefficient for this distribution was 0.58 and 0.57 for autonomous and monetary income, respectively, and the figures for this indicator remained unchanged in 2000. The 20/20 (quintiles) index, which measures the ratio between the average autonomous incomes of the fifth and first quintiles, rose from 14 to 15.3 between 1990 and 2000, while in the same period this ratio rose from 12.9 to 13.2 for monetary income. ${ }^{6}$

\footnotetext{
${ }^{6}$ Mideplan, Casen 1990 and 2000 surveys.
} 
TABLE 2

Chile: Social protection coverage by population group

\begin{tabular}{|c|c|c|c|c|c|c|c|c|c|}
\hline \multirow[b]{2}{*}{ Population group } & \multicolumn{9}{|c|}{ Function } \\
\hline & Old age & Survivors & Disability & $\begin{array}{l}\text { Occupational } \\
\text { accidents and } \\
\text { diseases }\end{array}$ & $\begin{array}{l}\text { Family } \\
\text { children }\end{array}$ & Sickness & $\begin{array}{l}\text { Public } \\
\text { health }\end{array}$ & Unemployment & $\begin{array}{l}\text { Poverty } \\
\text { and social } \\
\text { exclusion }\end{array}$ \\
\hline People with employment contract & $X$ & $\mathrm{X}$ & $\mathrm{X}$ & $\mathrm{X}$ & $\mathrm{X}$ & $\mathrm{X}$ & $X$ & $X$ & $\mathrm{X}$ \\
\hline Self-employed workers & $\mathrm{X}^{\mathrm{a}}$ & $\mathrm{X}^{\mathrm{a}}$ & $X^{a}$ & $\mathrm{X}^{\mathrm{b}}$ & $\mathrm{X}$ & $\mathrm{X}$ & $X$ & $\mathrm{X}$ & $X$ \\
\hline $\begin{array}{l}\text { Self-employed non-agricultural workers } \\
\text { and family members assisting them }\end{array}$ & $\mathrm{X}^{\mathrm{a}}$ & $\mathrm{X}^{\mathrm{a}}$ & $\mathrm{X}^{\mathrm{a}}$ & $\mathrm{X}^{\mathrm{b}}$ & $\mathrm{X}$ & $\mathrm{X}$ & $\mathrm{X}$ & $\mathrm{X}$ & $\mathrm{X}$ \\
\hline $\begin{array}{l}\text { Self-employed agricultural workers and } \\
\text { family members assisting them }{ }^{\mathrm{a}}\end{array}$ & $X^{a}$ & $\mathrm{X}^{\mathrm{a}}$ & $\mathrm{X}^{\mathrm{a}}$ & $\mathrm{X}^{\mathrm{b}}$ & $\mathrm{X}$ & $\mathrm{X}$ & $\mathrm{X}$ & $\mathrm{X}$ & $\mathrm{X}$ \\
\hline $\begin{array}{l}\text { Unemployed in receipt of some } \\
\text { unemployment benefit }{ }^{\mathrm{b}}\end{array}$ & $X^{c}$ & $X^{c}$ & $X^{c}$ & & $\mathrm{X}$ & $\mathrm{X}$ & $\mathrm{X}$ & $\mathrm{X}$ & $X$ \\
\hline $\begin{array}{l}\text { Unemployed not in receipt of any } \\
\text { unemployment benefit }{ }^{b}\end{array}$ & $\mathrm{X}^{\mathrm{c}}$ & $X^{c}$ & $\mathrm{X}^{\mathrm{c}}$ & & $\mathrm{X}$ & $\mathrm{X}$ & $\mathrm{X}$ & $\mathrm{X}$ & $\mathrm{X}$ \\
\hline $\begin{array}{l}\text { Adults dependent upon employed } \\
\text { persons (economically inactive } \\
\text { spouses, relatives) }\end{array}$ & $X^{\mathrm{a}}$ & $\mathrm{X}^{\mathrm{a}}$ & $X^{a}$ & & $\mathrm{X}$ & $\mathrm{X}$ & $\mathrm{X}$ & & $X$ \\
\hline Children of employed persons & & $X$ & & & $X$ & $X$ & $\mathrm{X}$ & & $X$ \\
\hline Other economically inactive & & & & & $\mathrm{X}$ & $\mathrm{X}$ & $\mathrm{X}$ & $\mathrm{X}$ & $X$ \\
\hline
\end{tabular}

Source: Arenas de Mesa and Benavides (2003).

a Entitled to contributory benefits such as old-age, survivor's or disability pensions only if they have voluntarily paid the required contributions. Otherwise, they are entitled only to apply for welfare pensions.

b Self-employed workers and family workers who voluntarily enrol in the system and pay contributions may be entitled to the benefits provided for by occupational accidents and diseases legislation.

c Entitled to contributory benefits such as old-age pensions only if they have paid the necessary contributions during periods of employment.

The stagnation of income distribution has given rise to a controversy about the mechanisms available to society for dealing with a problem of this scale that potentially calls into question the working of the economic and social model.

Between 1990 and 2000, social policy helped improve income distribution. The cash benefits provided by the State are highly focused on the lowincome quintiles. For this reason, income distribution looks better when the analysis includes monetary transfers by the public sector. When monetary income is considered, i.e., autonomous income plus monetary transfers by the State in the form of welfare pensions, unemployment benefits, the different types of family allowance, drinking water subsidies and others, income distribution is better in every year from 1990 to 2000 . In fact, the greatest contribution by social spending to improving income distribution was made in 2000 . When cash benefits are considered, the ratio of average incomes between the richest $20 \%$ of the population and the poorest $20 \%$ falls from 15.3 to 13.2 .
In 2000 , cash benefits represented just $14 \%$ of the monetary income of the first autonomous income quintile, $4.3 \%$ of the monetary income of the second quintile and $1.7 \%$ of the monetary income of the third quintile. According to the Casen 2000 survey, income distribution improves significantly when the monetary contribution of the main health and education programmes is calculated, owing to the targeting of these programmes. In 2000, for example, benefits in kind represented almost $59 \%$ of monetary income for the first autonomous income quintile, $23 \%$ for the second quintile and $11 \%$ for the third.

When income distribution is corrected to include cash benefits and a monetary value for benefits in kind, the ratio between the average incomes of the fifth and first autonomous income quintiles falls from 15.3 to 8.3 in 2000 . These figures show what a substantial progressive effect social policies have, not so much in terms of monetary incomes as in improved distribution of overall incomes when a monetary value is set on benefits in kind (figure 5). 
FIGURE 5

Chile: Composition of household incomes in the first and fifth autonomous per capita household income quintiles, 2000

(Percentages)
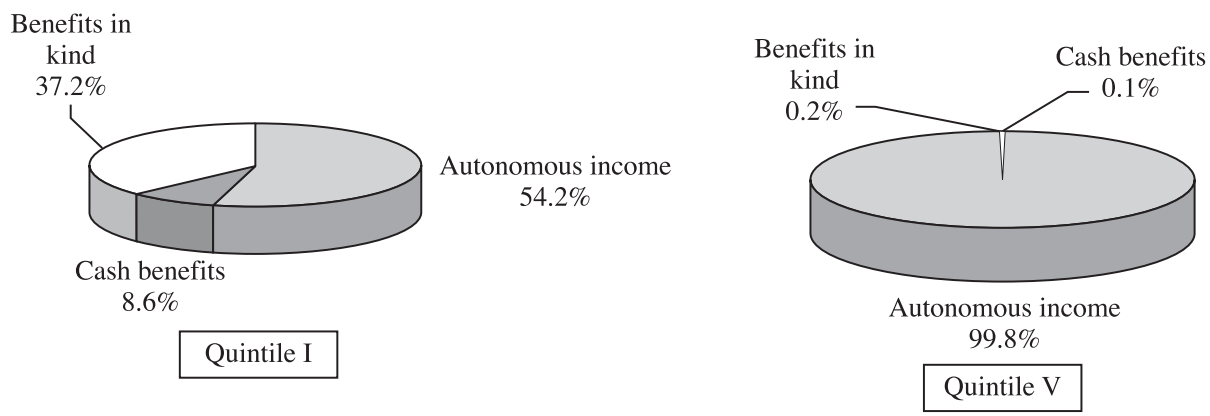

Source: Mideplan (2001).

IV

\section{Fiscal policy, contingent liabilities and social policy institutions}

\section{The role of fiscal policy in the development of social policy institutions}

\section{a) The scope of fiscal policy}

Alongside monetary and exchange-rate policy, fiscal policy plays a crucial role in creating the conditions for economic growth in the country, which is fundamental if a new level of development is to be achieved. The principal way in which fiscal policy can foster economic growth is by playing a stabilizing role in the short term and pursuing sustainability in the long term.

At the same time, fiscal policy has a preponderant function in the financing of social spending, which in 2002 represented more than $70 \%$ of total public-sector expenditure. The State has a responsibility for the country's social and cultural development that complements its role in economic development, and this is discharged by working to generate greater opportunities for people and by building a social protection network, particularly for those who are more deprived and do not have proper access to basic goods and services. Measures to achieve this include sectoral social policies for education, health care, housing and pensions and transversal social policies such as the full development of women and children at social risk and the eradication of poverty. It is essential for fiscal policy to provide stable, ongoing and effective financing for these policies, always seeking to improve the efficiency of public spending and the impact of the different programmes on the beneficiary population.

A good example of this are the bills to reform health care and set up the basic system of social protection known as Chile Solidario, which are going through Congress. In the first case, fiscal policy has not only sought to create budgetary frameworks for a system of health-care guarantees, but is concerning itself with the basic outlines of the desired health-care model. This has translated into a multitude of decisions about measures to strengthen primary care institutions, improve hospital management, implement a performance-related pay system for staff and develop health targets.

The Chile Solidario system represents an effort to create a new system of social protection that takes a comprehensive approach to extreme poverty, rather than simply supplying resources for implementation. The idea is that, with its national network, the Chile Solidario system should actively involve the State in identifying the neediest families so that benefits, 
payments and public-sector provision really do go to those who need them most. This also involves an effort to coordinate the social networks and services of the State and public-sector providers for the poorest so that they can meet the specific needs of every family by working directly and personally with each.

If it is considered that over $70 \%$ of public spending is social in nature, it can easily be imagined that different strategic decisions on government policy orientation, going beyond the mere allocation of resources, are being taken day by day. There also have to be decisions about the way the public sector is organized and structured in its different functions. The use made of fiscal resources cannot be optimized without regard to the institutional arrangements that exist, since these usually determine the efficiency of public spending on social programmes.

\section{b) Progress and challenges}

The public-sector institutions dealing with social programmes are the outcome of a range of factors, including the founding principles of the modern State, the structural reforms of past decades and the fiscal policies applied in recent years.

The institutional basis of the State has made it possible to build a broad, stable public-sector system capable of attending to social priorities. Through State action, basic tasks have been undertaken in areas such as education, health care, housing, pensions and social protection. At the same time, the State has been increasingly active in regulating the economic and financial life of the country.

As the State has developed, there has been a shift in the type of activities performed by the public sector. This has mainly meant a substantial reduction in the productive functions of the State and a reallocation of functions between it and the private sector, which has been particularly dramatic in the sphere of social services provision. At the same time, the fiscal adjustment process of the 1980s taught hard lessons about the importance of public spending control and fiscal discipline.

In the 1990-2003 period, progress was made with this fiscal discipline and with measures to strengthen the regulation and oversight functions, the subcontracting of services, the restoration of working conditions in the public sector and the creation and enhancement of different social programmes.

The challenge now is to allocate fiscal resources in public-sector and social programmes in a way that is macroeconomically efficient. There is now general agreement that the responsibility of the public-sector financial authority consists not just in spending within a framework of budgetary constraint, but in spending efficiently. For this it is important to recognize that financial management standards are crucial for the proper administration of public-sector institutions. The way resources are delivered and the responsibilities and commitments shared between the financial authority and administrative bodies largely determine the overall efficiency with which public funds are allocated and used.

By contrast with other countries, the institutional changes needed in the public sector do not centre on efforts to reduce staffing or cut chronic fiscal deficits. Rather, the need is to bring in management systems and procedures that ensure public resources are used as efficiently as possible and that enhance the overall impact of social policies on the beneficiary population.

Again, the sum of individual benefits and programmes does not necessarily constitute a social protection system. This is a problem that also affects most other countries in Latin America, partly because of the lack of a shared institutional framework, an information network linking together access services, thorough coordination among organizations and shared eligibility criteria.

These shortcomings result in the duplication of functions and in administration costs that undermine system inefficiency. Provision is often concentrated on beneficiaries who are better connected to the social network, with the result that potential beneficiaries who are not so connected are left uncovered. Even more importantly, synergies among the different organizations are forfeited owing to the lack of coordination.

To deal with these problems, there is a need to develop clear guidelines that give a preponderant role to fiscal policy. The dispersion of public-sector institutions and programmes is a challenge that needs to be dealt with, and the financial authority of the State can and should be applied to this objective in a comprehensive, transversal way through the functions currently performed by the different ministries, services and social programmes.

This is particularly important if we consider that there are currently some 400 social programmes involving 80 different institutions. At least 40 of these can be classed as social protection programmes.

The activities undertaken by these public-sector programmes and organizations have given citizens throughout the country greater access to basic social 
services. Progress needs to be increased, however, not just as regards coverage, but also from a strategic point of view with priority being given to improving the quality of these different aspects of public-sector action. To this end, a management control system has been developed and improved in recent years, and this uses instruments such as performance indicators, institutional and programme evaluations, competitive funds for the financing of public-sector investment and programmes, management improvement programmes and comprehensive management reviews. ${ }^{7}$

Notwithstanding this progress, there is a need to improve on the current quality standards of the public sector. Among other measures, this will mean focusing on its products and services and reorganizing its internal operations.

Included within this is a need to strengthen the pillars on which a basic system of social protection rests: coherence and informed access for beneficiaries; priority for the family; effective targeting on the neediest groups; the development of selection mechanisms and eligibility conditions that are consistent across the different programmes; and the existence of appropriate and coherent State institutions (Arenas de Mesa and Benavides, 2003).

In respect of all this, it is up to fiscal policy to harmonize the maintenance of fiscal balances and make public services more proactive and responsible, and not the central authority. There is also a need to move forward with modernization of the budgetary process and to create and improve mechanisms that stimulate the development of public-sector management.

\section{Contingent liabilities and the sustainability of social protection policies}

The growing importance of the intertemporal dimension in the public finances has resulted in greater attention being given to the evaluation and management of the fiscal risk associated with the effects of public-sector assets and liabilities on future revenue and expenditure flows.

Because so little attention was paid to the issue in the past, there are still problems with fiscal valuation, quantification and management of these medium-term effects or commitments. There are countries where rigid spending discipline has been exercised, but where the same discipline has not been applied to explicit or

\footnotetext{
${ }^{7}$ For further details, see Dirección de Presupuestos (2002).
}

implicit financial commitments that sooner or later will have to be met.

One issue of particular importance is that of contingent liabilities in the public sector, which can go unnoticed until they materialize, at which point there is little or no prospect of their being neutralized by shortterm measures.

The subject is particularly important from a social protection point of view, since if future fiscal commitments are not properly foreseen, there is a risk that resources intended for social ends may at some point have to be sacrificed to cover liabilities that have been accruing and maturing over time. This is why it is important to treat the management of contingent liabilities as one of the medium-term aspects of social protection policies.

a) Medium-term fiscal risks and contingent liabilities

The different types of public-sector liabilities can be classified by the fiscal risk associated with each, in the light of two complementary aspects. The first aspect is whether the liabilities are explicit or implicit, and the second is whether they are direct or contingent (Polackova, 1998).

By an explicit liability is meant one that is contractually or legally recognized. We speak of implicit liabilities, on the other hand, when what is at stake is rather a moral imperative or a statement of objectives, such as a commitment to assist the indigent or people who lack pension provision. The distinction between direct and contingent liabilities depends on whether a triggering event is involved. Direct liabilities must be met in all circumstances, i.e., no particular event is required to make them effective. Contingent liabilities arise only when a particular event occurs, e.g., the bankruptcy or insolvency of a financial institution.

In most countries, explicit direct liabilities are commonly recognized, quantified and classified as liabilities. Examples of these are the external publicsector debt and expenditure included in the budget act. Implicit direct liabilities, meanwhile, almost always arise as State obligations deriving mainly from mediumterm public policies. In Chile, welfare pensions (known as PASIS) belong to this category, and in this case the existence of a self-imposed legal obligation means that the State has an implicit commitment, of a moral and social nature, towards indigent people who lack pension provision.

Implicit contingent liabilities are not officially recognized and may derive from declared political objectives or political pressure from interest groups 
existing at a particular time. Examples of such liabilities include private-sector bank rescues by the State when a severe financial crisis occurs, liabilities generated when local governments fail to repay non-guaranteed debts, or aid to victims of natural disasters.

Explicit contingent liabilities are those that have most commonly been classified as true contingent liabilities. They are spelt out in advance by law or contract, but whether the associated expenditure is triggered and how much it amounts to depend on a particular event actually taking place. Examples of this kind of liabilities include the State deposit guarantee, the minimum revenue guarantee for transport concessions and the State minimum pension guarantee for the private-sector pension system.

The recent increase in liabilities of this type is largely due to the changing role of the State, which has tended to move from financing and providing services directly to guaranteeing the achievement of particular results by the private sector. Consequently, there is an increasing need for efforts to identify and quantify them on a systematic, ongoing basis.

\section{b) Contingent liabilities that are important in Chile}

For Chile, an initial analysis has identified four major contingent liabilities (Dirección de Presupuestos, 2001a). They are as follows:

i) The minimum revenue guarantee for transport concessions: contracts stipulate minimum revenues from tolls, guaranteed by the Ministry of Public Works, Transport and Telecommunications (MOP) for each year the concession is operated. If actual revenue is below the minimum, MOP has to make up the difference;

ii) The State deposit guarantee: banking obligations for term deposits and investments in the form of savings accounts or personal or bearer instruments held by natural persons specifically include a State guarantee of $90 \%$ if the bank should fail, with a limit of 108 UF per person. There is also a $100 \%$ State guarantee for current account deposits, sight deposits and other liquid financial instruments. The bankruptcy of financial institutions is the uncertain event that makes this liability a contingent one;

iii) Claims against the Treasury: the State and dependent institutions can be sued by individuals or organizations that believe they have been prejudiced by its activities. The fact that the State is only obliged to indemnify individuals if the ruling goes against the Treasury makes this a contingent liability; iv) The State minimum pension guarantee for the private-sector pension fund manager (AFP) system: the AFP system establishes that if the pension entitlement upon retirement of a worker who has paid at least 240 months of contributions is below a certain minimum, the State will make up the difference when that worker's individual account runs out. The obligation thus accepted by the Treasury is a subsidiary one, as its objective is to deal with the contingency whereby the resources accrued by the worker in his or her individual capitalization account, plus the bono de reconocimiento (an instrument representing the monetary value of payments into the pre-AFP system) where relevant, are insufficient to finance a minimum pension whose value is set by the State itself. Furthermore, this contingent liability is not the only obligation that arises for the State in relation to the pensions system. There is also the operating deficit of the old public pension system, payment of bonos de reconocimiento, welfare pensions (PASIS) and the deficit accrued on the military pensions paid by the armed forces and carabineros pension funds.

In quantifying these liabilities, it is usually necessary to distinguish between the maximum possible value of each and the expected value. An initial analysis conducted by the Ministry of Finance showed the total values of transport concessions to which minimum revenue guarantees applied and the maximum disbursement for which the State could be liable under the State deposit guarantee if every single banking institution were to fail, put at $28 \%$ of GDP. The study also includes the amounts paid out for claims against the Treasury and spending projections for the State minimum pension guarantee (Dirección de Presupuestos, 2001a).

There is also an obligation to submit to the National Congress, together with the 2004 budget bill, a supplementary financial report providing information on contingent liabilities, among other things. This report, which has now been presented, is in a standard format and contains information on variables that are not directly allowed for in the budget bill, but that may entail risks for the performance of the public finances in future. Another step in this direction is the creation of the Public Finances Division of the Budgetary Affairs Bureau which is responsible, among other functions, for supervising and administering the financial assets of public-sector enterprises and the relationship with multilateral banking organizations. 


\section{V}

\section{Concluding remarks}

\section{The modernization of fiscal policy}

The challenges involved in implementing, measuring and evaluating fiscal policy are of particular importance for developing countries such as Chile. Management of the public finances on an intertemporal, countercyclical basis as a key element in a social protection strategy requires progress to be made towards better measurement, supervision and management of contingent liabilities and their medium-term effects.

This is particularly important considering that in most countries contingent liabilities relate to off-budget programmes. This status has sometimes allowed liabilities of this type to be used as a way of carrying on with programmes without affecting the short-term fiscal balance. In the medium and long term, however, these contingent liabilities considerably increase fiscal risk and expose the Treasury to situations that could be destabilizing for the public finances, thereby reducing the ability of fiscal policy to play a preponderant role in social protection for the most vulnerable.

For this reason, there is a need to improve fiscal management methodologies and practices related to the handling of contingent liabilities. Requirements include increasing the transparency of information about offbudget liabilities and moving from cash budgets to accrual-basis budgets that include contingent liabilities.

In this context, fiscal policy plays a decisive role in the institutional design of social protection systems, not only to achieve stable, sustained financing of these programmes over time, but through the application of institutional designs that are compatible with financial and fiscal capabilities and that efficiently meet the needs of the most vulnerable.

\section{Challenges facing the social protection system}

In the 1990s, changes in social indicators in different sectors revealed significant progress with the quality and equity of social spending and improvements in its targeting. Furthermore, policies designed to achieve macroeconomic and social stability were implemented in a coordinated fashion, and it has been claimed as a result that 1990s fiscal policy was an important factor in achieving economic and political stability.
The social protection system also faces new challenges, such as the demographic transition and the growing participation of women in the labour market. Combined with the levelling off of the indigence rate in 1996, 1998 and 2000, these changes suggest that a new strategy needs to be designed and executed so that instruments and policies intended to help those in extreme poverty can achieve the objective of delivering a basic social protection network.

Within this frame of reference, Chile needs to modernize the social protection system and implement a new institutional structure. One of the main tasks is an institutional redesign to strengthen and rationalize the State institutions responsible for the basic system of social protection, including an exhaustive review of all current benefits, transfers, funds and support programmes that do not form part of the core tasks of the sectoral ministries (education, health and housing) or contributory social security programmes, and then to develop out of them a system of social protection under the charge of a single institution, which is the "one-stop shop" concept. This one-stop shop principle should inform the organization of the new social protection system and be applied both at a macro institutional level and at the micro level of the individual beneficiary. At the macro level, management, resources and social protection network policy design need to be brought together in a single institution. At the micro level, a unified service to beneficiaries should mean better integration of different aspects of public-sector activity, simplified access to provision as unnecessary levels of interaction are done away with, and integration of activities, improving the targeting and efficiency of social protection.

Whether or not success is achieved in reducing indigence will largely depend on the institutional arrangements that determine how and where benefits are delivered. Particular attention needs to be paid, too, to the way in which these instruments actually reach beneficiaries. For indigence to be reduced, it may not be enough to offer instruments and benefits. A proactive approach also needs to be applied, centring on demand and beneficiaries, as this has the potential to increase the efficiency of the mechanisms designed. Such efforts to seek out demand, which must necessarily have a 
strong local component, also need to be properly coordinated with the "one-stop shop" described above.

Another principle that needs to be considered in any new institutional design is the targeting unit. The unit of reference for the targeting of public action should be the family, and not the individual. Thus, the targeting of social protection could be improved by using a concept of family income that takes account of an actual family situation, understood as an overarching group that maintains close links rather than as the sum of the situations of individuals considered separately.

The same holds for targeting criteria, the third key principle of the new institutional arrangements needed for the basic social protection system. Although the great majority of social protection programmes are already closely targeted, there are still major challenges in this area. The results in terms of social protection achieved in the 1990s show the importance of proper targeting and the redistributive effects that social protection programmes can have. International evidence shows that the poverty reduction process can advance at different speeds in economies with similar growth rates. This is largely due to differences in income concentration and the rapidity with which this improves (ECLAC, 2002). In future, one of the key factors in achieving good results with poverty reduction will be proper targeting of the benefits of the social protection system. The more closely targeted public-sector action is, the greater and more rapid the social results will be. Specifically, the social protection system should give priority to the indigent and poor populations, particularly in the countryside.

Along with institutional redesign of the social protection system, it will be essential to strengthen, expand and in some cases implement information systems for social protection policies. The selection mechanism currently used, the CAS II information system, will have to form part of this adaptation process so that new information requirements are properly met and social programmes are efficiently targeted. A new information and selection system could be used to improve social policy evaluation and follow-up and to cope with economic, demographic and social transition, which will require social protection systems to be continually reviewed and adapted.

This type of design will be conducive to greater public policy integration and to the coordination of sectoral efforts, and will prevent duplication of effort and waste of public resources. The only potential constraint on the basic social protection network will be budgetary restrictions, since it is these that limit the value of benefits and the number of new beneficiaries, for example, in the welfare pensions and family benefit system. One way of modernizing the social protection network would be to provide more benefits to those who best qualify for them in the case of extreme poverty and reaffirm their right to these benefits, which confirms still more the need for institutional redesign to guarantee these families' rights. Applying an approach of this kind, in conjunction with the other challenges facing the social protection network, is the basis for a new social policy strategy to reduce indigence and extreme poverty.

In summary, we can say that sustained economic development is the basic precondition for solving the problem of poverty and creating a stable, integrated system of social protection that gives people equality of opportunity. Social deprivation is an obstacle to any ambitions for a democratic society.

\section{Bibliography}

Arellano, J.P. (1985): Políticas sociales y desarrollo. Chile 1924 1984, Santiago, Chile, Economic Research Corporation for Latin America (CIEPLAN).

Arenas de Mesa, A. (2000): Cobertura previsional en Chile: lecciones y desafíos del sistema de pensiones administrado por el sector privado, Financiamiento del desarrollo series, No. 105, LC/L.1457-P, Santiago, Chile, ECLAC, December. United Nations publication, Sales No. S.00.II.G.137.

Arenas de Mesa, A. and P. Benavides (2003): Protección social en Chile, financiamiento, cobertura y desempeño: 1990-2000, Santiago, Chile, International Labour Organization (ILO).

De Ferranti, D., G. Perry and others (2000): Securing Our Future in a Global Economy, Washington, D.C., World Bank, June.
Dirección de Presupuestos (2000): Estadísticas de las finanzas públicas, 1990-1999, Santiago, Chile, Ministry of Finance. (2001a): Identificación y cuantificación estimativa del conjunto de pasivos contingentes y otras obligaciones futuras del sector público, Santiago, Chile, Ministry of Finance. (2001b): Estadísticas de las finanzas públicas, 1991-2000, Santiago, Chile, Ministry of Finance.

(2002): Informe de finanzas públicas. Proyecto de Ley de Presupuestos del sector público del año 2003, presented by Mr. Mario Marcel, Santiago, Chile, October.

ECLAC (Economic Commission for Latin America and the Caribbean) (2002): Preliminary Overview of the Economies of Latin America and the Caribbean, 2002, LC/G.2196-P, 
Santiago, Chile. United Nations publication, Sales No. E.02.II.G.126.

Fiess, N. (2002): Chile's New Fiscal Rule, Background Paper, No. 3, Washington, D.C., World Bank, May.

Marcel, M. and M. Tokman (2002): Building a consensus for fiscal reform: the Chilean case, OECD Journal on Budgeting, vol. 2, No. 3, Paris, Organisation for Economic Co-operation and Development (OECD).

Marcel, M., M. Tokman and others (2001): Balance estructural del gobierno central: metodología y estimaciones para Chile: 1987-2000, Estudio de finanzas públicas series, Santiago, Chile, Ministry of Finance, September.

Mideplan (Ministry of Planning and Cooperation) (2001): Pobreza e indigencia e impacto del gasto social en la calidad de vida. Informe ejecutivo, Santiago, Chile, July.

Ministry of Finance (2001): Exposición sobre el estado de la hacienda pública 2001, presentation by Mr. Nicolás Eyzaguirre, Minister of Finance, Santiago, Chile, October.

(2002a): Estadísticas de la deuda pública, 1989-junio 2002, Santiago, Chile, October [www.minhda.cl].

(2002b): Exposición sobre el estado de la hacienda pública 2002, presentation by Mr. Nicolás Eyzaguirre, Minister of Finance, Santiago de Chile, October.
(2003): Informe de estadísticas de la deuda pública, Santiago, Chile, April [www.minhda.cl].

Perry, G. (2002): Can Fiscal Rules Help Reduce Macroeconomic Volatility in LAC?, document prepared for the Conferece "Reglas macro-fiscales en economías de mercados emergentes" (Oaxaca, Mexico, 14-16 February 2002).

Polackova, H. (1998): Government Contingent Liabilities: A Hidden Risk to Fiscal Stability, Policy Research Working Paper, No. 1989, Washington, D.C., World Bank.

Snyder, J. and I. Yackovlev (2000): Political and Economic Determinants of Government Spending on Social Protection Programs, Massachusetts, Massachusetts Institute of Technology, April.

Tokman, V. (2001): Hacia una visión integrada para enfrentar la inestabilidad y el riesgo, document presented at the Workshop on macroeconomics and poverty (Santiago, Chile, 18-20 December), Santiago, Chile, ECLAC, preliminary version.

Wodon, Q., N. Hicks and others (1999): Are Governments Pro-poor? A Test Based on Targeted and Social Spending During Booms and Busts, World Bank Draft Paper, Washington, D.C., World Bank. 